\title{
Soil fertility and uptake as influenced by different intercropping in summer pearlmillet (Pennisetum glaucum L.)
}

\author{
B.L. YADAV*, B.S. PATEL ${ }^{1}$ AND S.K. YADAV ${ }^{2}$ \\ Department of Agronomy, C.P. College of Agriculture, Sardarkrushinagar Dantiwada Agricultural University, \\ SARDARKRUSHINAGAR (GUJARAT) INDIA
}

\begin{abstract}
A field experiment was conducted during the summer season 2010 at Agronomy Instructional Farm, Department of Agronomy, Chimanbhai Patel College of Agriculture, Sardarkrushinagar Dantiwada Agricultural University, Sardarkrushinagar (Gujarat) to study on intercropping in summer pearlmillet [Pennisetum glaucum (L.) R. Br. Emend. Stuntz]. Thirteen treatments of sole crops and intercropping systems viz., $\mathrm{T}_{1}$ : pearlmillet sole, $\mathrm{T}_{2}$ : cowpea sole, $\mathrm{T}_{3}$ : greengram sole, $\mathrm{T}_{4}$ : mothbean sole, $\mathrm{T}_{5}$ : sesame sole, $\mathrm{T}_{6}$ : pearlmillet + cowpea $(1: 1), \mathrm{T}_{7}$ : pearlmillet + cowpea $(1: 2), \mathrm{T}_{8}$ : pearlmillet + greengram $(1: 1), \mathrm{T}_{9}:$ pearlmillet + greengram $(1: 2), \mathrm{T}_{10}$ : pearlmillet + mothbean $(1: 1), \mathrm{T}_{11}$ : pearlmillet + mothbean $(1: 2), \mathrm{T}_{12}$ : pearlmillet + sesame $(1: 1)$ and $\mathrm{T}_{13}$ : pearlmillet + sesame $(1: 2)$ were evaluated in a Randomized Block Design with three replications. The soil was loamy sand, neutral ( $\mathrm{pH} 7.0)$ low in organic carbon $(0.17 \%)$, available nitrogen (149 kg N/ha), medium in available phosphorus (46 $\mathrm{kg} \mathrm{P}_{2} \mathrm{O}_{5} / \mathrm{ha}$ ) and high in potassium $(281 \mathrm{~kg} \mathrm{~K} \mathrm{O} / \mathrm{ha}$ ). The higher available nitrogen, phosphorus and potassium were observed in pulses sole and intercropping systems. Green gram sole established its superiority by recording available nitrogen, phosphorus and potassium. Intercropping of cowpea, greengram, mothbean and sesame at 1:1 and 1:2 row ratios in pearlmillet recorded significantly higher N, P and K content (\%) of pearlmillet. While, in case of $\mathrm{N}$ content (\%) found significantly higher in intercrops when grown as sole crop, but $\mathrm{P}$ and $\mathrm{K}$ content (\%) found higher in intercropping systems. Maximum total N, P and $\mathrm{K}$ uptake of pearlmillet was recorded under sole crop, though when pearlmillet crop intercropped with pluses and sesame crop. All intercrops sown as sole crop recorded higher total $\mathrm{N}$, $\mathrm{P}$ and $\mathrm{K}$ uptake as compared to intercropped in pearlmillet.
\end{abstract}

Key Words : Pearlmillet, Cowpea, Greengram, Mothbean, Sesame, Cropping system,

View Point Article : Yadav, B.L., Patel, B.S. and Yadav, S.K. (2015). Soil fertility and uptake as influenced by different intercropping in summer pearlmillet (Pennisetum glaucum L.). Internat. J. agric. Sci., 11 (1): 68-72.

Article History : Received : 28.05.2014; Revised : 07.11.2014; Accepted : 24.11.2014

\footnotetext{
* Author for correspondence

${ }^{1}$ AICRP-IFS, Sardarkrushinagar Dantiwada Agricultural University, SARDARKRUSHINAGAR (GUJARAT) INDIA

${ }^{2}$ Department of Horticulture, C.P. College of Agriculture, Sardarkrushinagar Dantiwada Agricultural University, SARDARKRUSHINAGAR (GUJARAT) INDIA
} 